\title{
Cytotoxic Activity on MCF-7 Cells and in Silico Study of Sapogenin Steroids from Trigonella foenum-graecum $L$.
}

\author{
Kurnia Agustini*, Firdayani, Churiyah \\ Center for Pharmaceuticals and Medical Technology \\ Laboratory for Development of Industrial Agro and Biomedical Technology \\ Agency for the Assessment and Application of Technology (BPPT) \\ Kawasan PUSPIPTEK, Serpong, Indonesia
}

\begin{abstract}
Trigonella foenum-graecum (TFG) is one of medicinal plants containing several steroidal sapogenins, such as diosgenin, yamogenin, gitogenin, tigogenin and trigoneoside, and also alkaloid trigonellin and some flavonoids such as vitexin, isovitexin, orientin, isoorientin, which has many activities, such as antidiabetic, estrogenic, and also anticancer. As phytoestrogen, TFG was predicted to have potency as Selective Estrogen Receptor Modulators (SERMs) which is used for hormonal-dependent breast cancer treatment. This experiment was carried out to investigate interaction of some sapogenin steroids and flavonoids in TFG to estrogen receptor alpha $(E R \alpha)$ and its activity to breast cancer cell line as confirmation. In silico prediction was carried out to investigate their estrogenic activity by analyzing their binding affinity to ER $\alpha$ using AutoDock Vina program. In vitro activity confirmation of TFG extract and its fractions were carried out using MTT assay on Era-positive human breast cancer cell line, MCF-7. Results showed that free binding energies of diosgenin and yamogenin were $-6.4 \mathrm{kcal} / \mathrm{mol}$, estradiol was $-6.0 \mathrm{kcal} / \mathrm{mol}$, and tamoxifen was $-5.1 \mathrm{kcal} / \mathrm{mol}$. While cytotoxicity assay showed that ethyl acetate fraction gave the lowest $\mathrm{IC}_{50}$ of $4 \mathrm{I} .8 \mathrm{I} \mathrm{ppm}$, with total steroid content of $20.03 \mathrm{ppm}$. From these results, we can conclude that diosgenin and yamogenin have greater binding affinity to ER $\alpha$ comparing to estradiol and tamoxifen. In vitro assay confirmation showed that ethyl acetate fraction has cytotoxic effect on MCF-7 cells.
\end{abstract}

Keywords: Trigonella foenum-graecum, sapogenin steroids, MCF-7, estrogen receptor alpha, binding affinity.

\section{INTRODUCTION}

Fenugreek seed or Foenigraeci semen is dried seed from Trigonella foenum-graecum L., (TFG), Leguminosae, (WHO, 2007). Empirically, TFG seed is used for treating hemorrhoids, asthma, ulcers, and muscle pain, and is often used to prevent hair loss, and also as skin softener. Many studies revealed its activity as antidiabetic, anticancer, and for hypercholesterolemia handling (Mills, et al., 2000). TFG has antiandrogen activities, due to its active compounds as betasitosterol, palmitic-acid, and stearic-acid, and also has the ability to decrease total cholesterol, LDL, VLDL cholesterol, and triglycerides significantly. The anti-hyperglycemic and anti-inflammatory properties investigated in fenugreek are additional benefit. TFG can induce uterine contraction, so it can not be consumed during pregnancy (Hoffman, 2004). Agustini, et al. (2007) showed that ethanolic extract of TFG seed have estrogenic effect on ovariectomized and immature female Wistar rats. Phytoestrogen is used as alternative for Hormone Replacement Therapy (HRT) to help reducing menopause symptoms. It can be used for long term therapy until the body can make adaptation on the new hormone level (Badziad,
2003). Phytoestrogens also have potency to handle hormonal-depending breast cancer which is known as natural Selective Estrogen Receptor Modulators (SERMs).

TFG was predicted to have estrogenic-like effect, also because of some sapogenin steroid contents, e.g., diosgenin, precursor for sexual hormone (Evans, 2002), its isomer Yamogenin (Dewick, 1997), gitogenin, tigogenin, and trigoneoside (saponin-like estrogen) which have effect as phytoestrogen for menopause symptoms therapy (Hoffman, 2004) (Fig. 1). TFG seed contains $0.8-2.2 \%$ diosgenin in free base form (Wiryowidagdo, 2000).

TFG also contains 20-30\% fatty oil, alkaloids (trigonelline, an alkaloid pyridine, gentianin, and karpain), flavonoids e.g. vitexin in glycoside or ester form, isovitexin, orientin, vicenin, quercetin, and luteolin (Hoffman, 2004), essential oil, saponine, nicotinamide, choline, bitter compound, and mucilage (Evans, 2002).

\footnotetext{
$\overline{\text { *Corresponding author e-mail: kurnia_atini@yahoo.com }}$
} 
<smiles>C[C@@H]1CCC2(OC1)OC1CC3C4CC=C5C[C@@H](O)CC[C@]5(C)C4CC[C@]3(C)C1[C@H]2C</smiles>

(A)

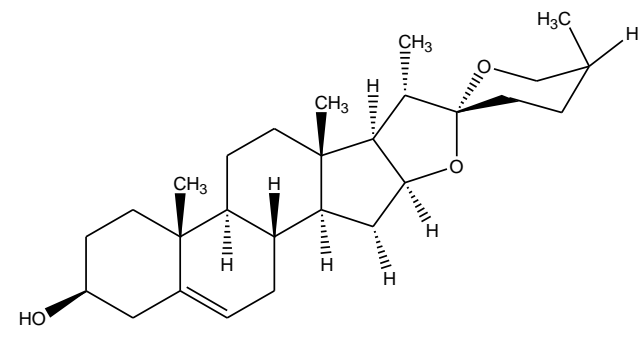

(B)

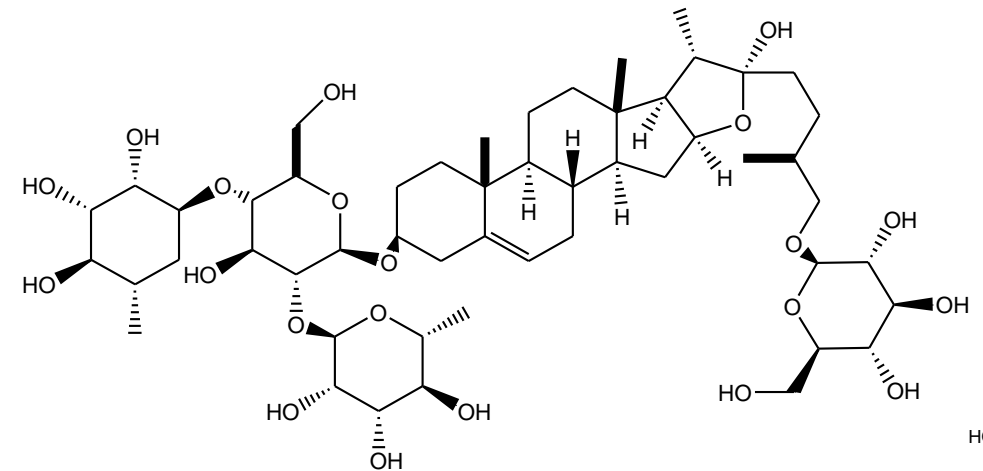

(C)

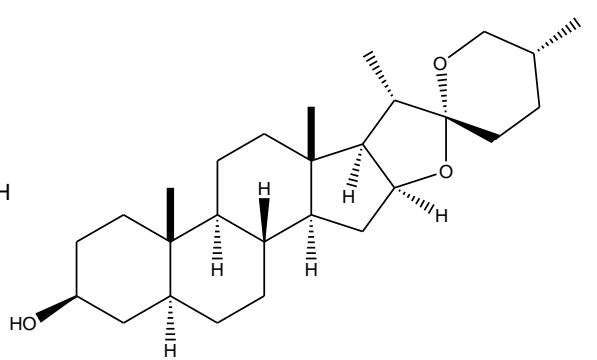

(D)

Figure I. Sapogenin Steroids of Trigonella foenum-graecum L.: diosgenin (A), yamogenin (B), protodioscin (C), and tigogenin (D).

This study was carried out to investigate interaction from some sapogenin steroids and flavonoids in TFG to estrogen receptor alpha $(\mathrm{ER} \alpha)$ in silico and the cytotoxicity activity of fenugreek seed to breast cancer cell line with estrogen receptor positive as confirmation.

The in silico study was carried out to investigate their estrogenic activity by analyzing their binding affinity to ER $\alpha$ using AutoDock Vina program. In vitro confirmation activity of TFG extract and its fractions were carried out using MTT assay on ER $\alpha$-positive human breast cancer cell line, MCF-7.

\section{MATERIALS AND METHODS}

\section{Docking Simulation}

Docking simulation was carried out to predict interaction of $\mathrm{ER} \alpha$ (PDB ID: 2YAT) as protein receptor and four steroid sapogenins (Diosgenin, Tigogenin, Gitogenin, and Protodioscin) of TFG, estradiol, and tamoxifen as ligands. Ligands and macromolecules files were prepared by MGL Tools 1.5.4 software. Docking was carried out to investigate ligands' estrogenic activity by analyzing their binding affinity to ER $\alpha$ using AutoDock Vina program. The size of the docking grid was $40 \AA \times 40 \AA \times 40 \AA$, which encompassed the entire $\mathrm{ER} \alpha$ structure. Visualization of the interactions were done using PyMol.

\section{Sample Preparation}

TFG seed were obtained from Tawangmangu, Central Java, Indonesia. Seeds were dried and ground, then were extracted with methanol and ethanol. The methanolic extract was fractioned with n-hexane, ethylacetic (EtOAc), and n-buthanol. All the extracts and fractions were dried with vacuum rotary evaporator.

\section{Total Steroid Analysis}

This method was conducted bassed on Chapagin, et al., 2005. As many as $1 \mathrm{mg}$ dried extract/fraction was diluted in $2 \mathrm{~mL}$ ethylacetate in a tube, then $1 \mathrm{~mL}$ reagent $\mathrm{A}$ (containing $\mathrm{p}$ anysaldehyde and ethylacetate $(0.5: 99.5))$ and 1 $\mathrm{mL}$ reagent $\mathrm{B}$ (containing glacial sulfuric acid and ethyl acetate (1:1)) were added. The tube was put in $60^{\circ} \mathrm{C}$ water bath for 10 minutes until the color changed and then cooled in $25^{\circ} \mathrm{C}$ water bath for 10 minutes. Color intensity was measured by spectrophotometer UV Vis $423 \mathrm{~nm}$, against ethyl acetate solution as blank. Results were compared with standard curve of Diosgenin (Sigma).

\section{Cell Culture}

The MCF-7 cells (Human Breast Cancer with Estrogen Receptor Positive) were obtained from Laboratory for Development of Industrial Agro and Biomedical Technology (LAPTIABBPPT) Indonesia. Cells were routinely maintained and grown in $75 \mathrm{~cm}^{2}$ flasks at $37^{\circ} \mathrm{C}, 5 \% \mathrm{CO}_{2}$ in a 
95\% humidified atmosphere. The growth medium was prepared as following: RPMI 1640 (Gibco) with phenol red and $2 \mathrm{mM}$ glutamine, $100 \mathrm{U} / \mathrm{mL}$ penicillin, $0.1 \mathrm{mg} / \mathrm{mL}$ Streptomycin, $1 \mathrm{mM}$ sodium pyruvate, and supplemented with $10 \%$ Fetal Bovine Serum (FBS) (Gibco) which had been heat-inactivated at $56^{\circ} \mathrm{C}$ for 30 minutes. Passaging of cells was carried out using $4 \mathrm{~mL}$ trypsin-EDTA exposure at room temperature in $75 \mathrm{~cm}^{2}$ flask for 3 minutes. After that, $10 \mathrm{~mL}$ media with $10 \%$ FBS was used to reduce the action of trypsin on cells. After centrifugation, the obtained cells were platted.

\section{Cytotoxicity test with MTT assay}

Cells were distributed into 96-well plates (10,000 cells/well) in medium RPMI with phenol red containing $10 \% \mathrm{FBS}, 100 \mathrm{U} / \mathrm{mL}$ penicillin, 0.1 $\mathrm{mg} / \mathrm{mL}$ streptomycin, and $1 \mathrm{mM}$ sodium pyruvate, then incubated for 24 hours at $37^{\circ} \mathrm{C}, 5 \% \mathrm{CO}_{2}$ in a 95\% humidified atmosphere. After 24 hours, medium was changed with samples (extracts and phases of TFG) in growth medium in different concentration and incubated for another 24 hours at $37^{\circ} \mathrm{C}, 5 \% \mathrm{CO}_{2}$ in a $95 \%$ humidified atmosphere. Assays were done in a wide range of concentration, from 10 ppm until 500 ppm, divided into six concentrations variation.

After 24 hours treatment, the cells were washed with Phosphate Buffer Saline (PBS). Then the 3-(4,5-Dimethylthiazol-2-yl)-2,5 Diphenyltetrazolium (MTT) solution in medium was added, followed by incubation for 4 hours at $37^{\circ} \mathrm{C}, 5 \% \mathrm{CO}_{2}$ in a $95 \%$ humidified atmosphere. The crystal of blue formazan will be formed. After that, reaction was stopped by adding Sodium Dodecyl Sulphate (SDS) into each well. Leave plate in a dark place for 12 hours (overnight). The intensity of the color formed was measured by ELISA reader at $570 \mathrm{~nm}$.

\section{RESULTS AND DISCUSSION}

Recent studies suggest that TFG and its active compounds may possess anticarcinogenic activity. Raju, et al. (2004) showed that diosgenin, a steroidal saponin from TFG could inhibit azoxymethane-induced aberrant crypt foci formation in F344 rats and induce apoptosis in HT-29 human colon cancer cells. Referring to Agustini, et al. (2007), TFG had estrogenic effect on ovariectomized and immature rats. Some phytoestrogens are believed to have SERMs activity with no action in the uterus but beneficial effects in the hypothalamus/pituitary and in the bone (Wuttke, et al., 2003). According to Johnston (2005), the study to search the ideal profile of a novel SERMs should be done by finding a molecule having greater binding affinity into ER in comparison with tamoxifen, and also having ability to antagonize estrogen-dependent growth of breast cancer cells in vitro (preclinical).

Interaction of TFG active compounds with ER was predicted in silico using docking simulation method, which was carried out with AutoDockVina program. Free binding energy of interaction between some steroidal sapogenins steroids to ER $\alpha$ is showed in Table 1.

The docking process was started with protein preparation. During docking, series of poses (ligand-protein complexes) were generated for each molecule. Docking simulations was carried out on the Active Binding Sites such as, Ser 381, Cys 447, Ser 530. Table 1 shows the calculated free binding energy $\left(\Delta \mathrm{G}_{\text {bind }}\right)$ and the residue contact of flexible-ligand docking simulation. The negative and low value of $\Delta \mathrm{G}_{\text {bind }}$ indicated the strong favorable bond between protein and ligand. Based on docking simulation result, diosgenin, yamogenin, vitexin, and isovitexin could be proposed as a potential inhibitor, but a further study still need to be conducted. The docking visualization can be seen at Fig. 2 .

Table I. Predicted ligand free binding energy and residue contact in docking simulation

\begin{tabular}{cccc}
\hline No. & Compounds & Predicted $\Delta \mathbf{G ~ ( k c a l / m o l )}$ & Binding site \\
\hline I. & Estradiol & -6.0 & Arg 548, Arg 5I5 \\
2. & Tamoxifen & -5.1 & Ser 38I, Ala 546 \\
3. & Diosgenin & -6.4 & Arg 515 \\
4. & Protodioscin & -5.4 & Glu 380, Asn 519, Arg 548, Asp 545 \\
5. & Tigogenin & -6.0 & - \\
6. & Yamogenin & -6.4 & - \\
\hline
\end{tabular}




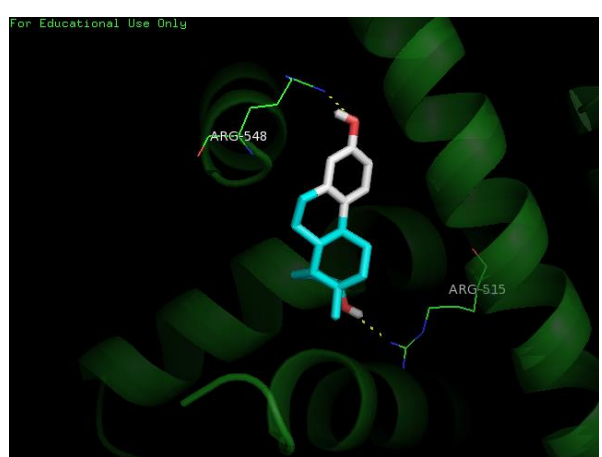

(A)

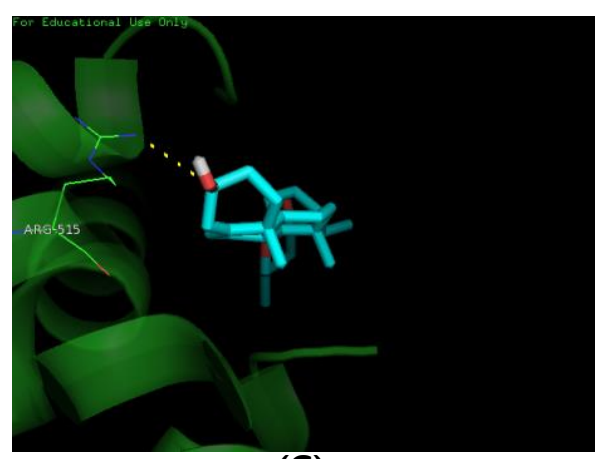

(C)

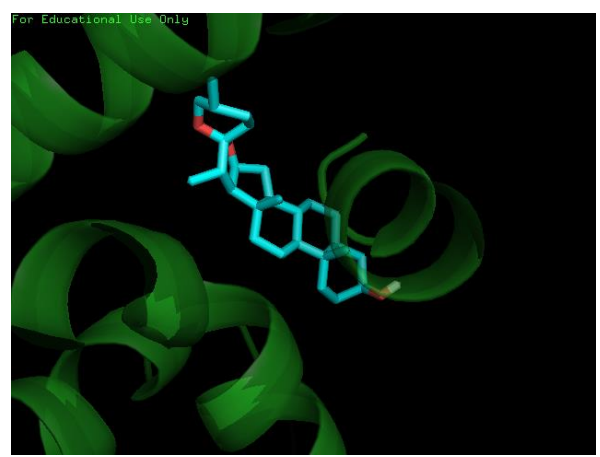

(E)

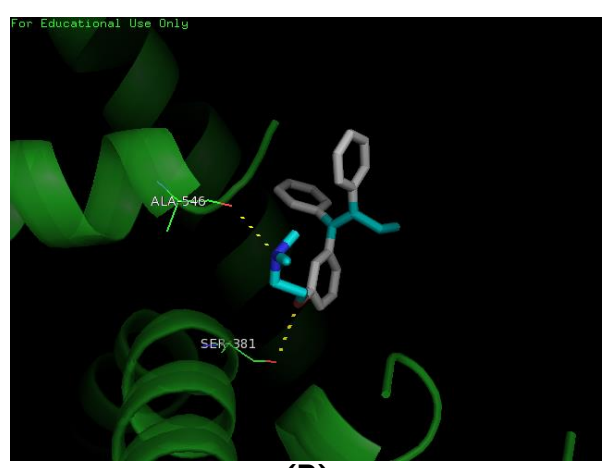

(B)

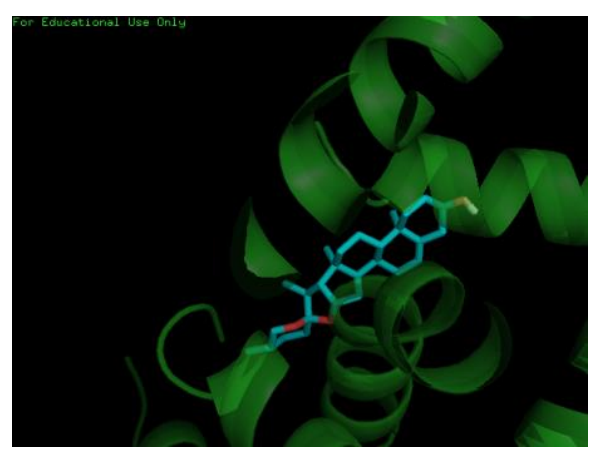

(D)

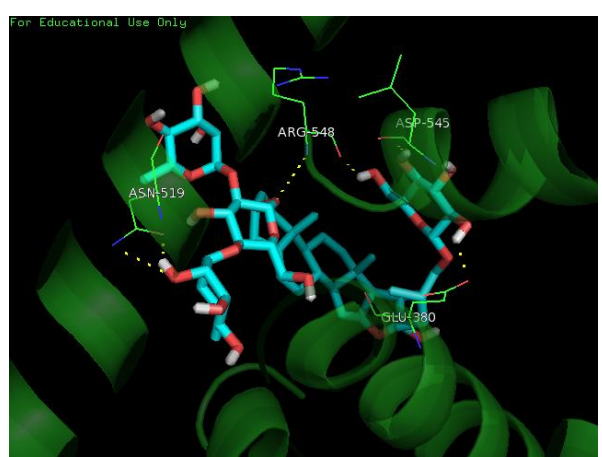

(F)

Figure 2. The visualization of the interaction in active binding site of ERa with some ligands: (A) estradiol, (B) tamoxifen, (C) diosgenin, (D) yamogenin, (E) tigogenin, and (F) protodioscin.

Total steroids level analyses showed that butanolic fraction contains the highest total steroid (25.321 ppm) while for $\mathrm{IC}_{50}$ on MCF-7 cells, ethylacetic fraction gave the lowest $\mathrm{IC}_{50}(58.63$ ppm). Total steroids analyses results and IC50 on MCF-7 can be seen on Table 2. While the growth percentage of MCF-7 cells treated with TGFare shown in Table 3. Total steroidal content in buthanolic fraction $(25.32 \mathrm{ppm})$ is nearly the same with ethylacetic fraction (20.03 ppm).

The major steroidal sapogenin from TFG, diosgenin, has been investigated in many researches for its cytotoxic activity. Moalic, et al. (2001) reported that diosgenin inhibited cell proliferation in human osteosarcoma 1547 cell line by induction of apoptosis and G1 phase cell cycle arrest. 
Table 2.Total steroid level and IC 50 of some fraction of TFG on MCF-7 cells

\begin{tabular}{lcc}
\hline & $\begin{array}{c}\text { TOtAL STEROID LEVEL } \\
(\mathrm{ppm})\end{array}$ & $\begin{array}{c}\text { IC50 on MNF-7 } \\
(\mathrm{ppm})\end{array}$ \\
\hline Ext.MetOH & 19.77 & 186.09 \\
Fr. EtOAc & 20.03 & 41.81 \\
Fr. N-Hex & 3.86 & 102.11 \\
Fr. N-BuOH & 25.32 & 136.25 \\
\hline
\end{tabular}

Table 3. Percentage growth of Trigonella foenum-graecum $L$ on MCF-7 cells

\begin{tabular}{cccccc}
\hline \multirow{2}{*}{$\begin{array}{c}\text { Concentration } \\
(\text { Ppm) }\end{array}$} & $\begin{array}{c}\text { MeOH } \\
\text { extr. }\end{array}$ & $\begin{array}{c}\text { EtOAc } \\
\text { Phase }\end{array}$ & $\begin{array}{c}\text { Hexane } \\
\text { Phase }\end{array}$ & $\begin{array}{l}\text { BuOH } \\
\text { Phase }\end{array}$ & Water Phase \\
\cline { 2 - 6 } & 110.609 & 78.722 & 75.166 & 107.737 & 100.889 \\
10 & 111.212 & 78.541 & 92.706 & 97.804 & 107.946 \\
20 & 98.674 & 30.199 & 82.821 & 73.131 & 102.248 \\
50 & 46.655 & 19.470 & 46.896 & 32.253 & 100.052 \\
100 & 18.565 & 17.963 & 18.987 & 20.544 & 92.211 \\
250 & 17.058 & 17.902 & 18.867 & 18.819 & 73.340 \\
500 & & & & & \\
\hline
\end{tabular}

Yoshihiro, et al. (2001) studied about cytotoxic activities on HL-6 human promyelocytic leukemia cells and structure-cytotoxic relationships of steroidal saponins. They found that the activities of some sapogenin steroids were sensitive to the monosaccharides constituting the sugar moieties and their sequences, as well as to the structures of the aglycons. They also concluded that structure-activity relationships of (25R)-Spirost-5-en-3b-ol (Diosgenin) glycoside derivatives Diosgenin b -D-glucoside showed no cytotoxic activity against HL-60 cells $\left(\mathrm{IC}_{50}>20 \mathrm{ppm}\right)$.

\section{CONCLUSION}

Diosgenin and yamogenin have greater binding affinity with ER $\alpha$ compared to estradiol and tamoxifen. In vitro assay confirmation showed that ethyl acetate fraction have cytotoxic effect on MCF-7 cells ( $\left.\mathrm{IC}_{50} 41.81 \mathrm{ppm}\right)$ and contains steroids (20.03 ppm).

\section{REFERENCES}

Agustini, K., Wiryowidagdo, S. and Kusmana, D., 2007, Estrogenic Effect of Fenugreek (Trigonellafoenum-graecum L.) on White
Female Rats, Conference Proceedings "Women's Health and Traditional Medicine", International Medicine and Medicinal Plants, Surabaya.

Agustini, K., Wiryowidagdo, S. and Kusmana, D., 2005, Pengaruh Pemberian Biji Klabet (Trigonella foenum-graecum L.) terhadap Kadar Hormon Estradiol dan FSH Plasma Tikus Putih Betina Galur Wistar yang Diovariektomi, Prosiding Seminar Nasional Penggalian Potensi Sembilan Tanaman Obat Unggulan Indonesia, Purwokerto.

Agustini, K., Wiryowidagdo, S. and Kusmana, D., 2005, Efek Estrogenik Biji Klabet (Trigonella foenum-graecum L.) terhadap Perkembangan Uterus Tikus Putih Betina, Jurnal Bahan Alam Indonesia, 4 (2), 280-285.

Annida, B. and Prince, P.S.M., 2004, Supplementation of Fenugreek Leaves Lower Lipid Profile in Streptozotocininduced Diabetic Rats, J. Med. Food, 7(2), I53-156.

Badziad, A., 2003, Endokrinologi Ginekologi, Jakarta: Media Aesculapius.

Bhat, K.P.L, Lantvit, D., Christov, K., Mehta, R.G, Moon, R.C. and Pezzuto, J.M., 200I, Estrogenic and Antiestrogenic Properties of 
Resveratrol in Mammary Tumor Models, Cancer Res., 6 I (20), 7456-7463.

Dewick, PM, 1997, Medicinal Natural Products. A Biosynthetic Approach, New York: John Wiley \& Sons.

Evans, CW, 2002, Pharmacognosy, 15th edition, London: W.B. Saunders.

Ibieta, P., 2005, Interaction of Phytoestrogens with Rat Uterine Estrogen Receptor, Human Sex Hormone-Binding Globulin and Human Breast Adenocarcinoma Cells (MCF-7), Dissertation, Institute for Pharmacy and Molecular Biotechnology, University of Heidelberg, Heidelberg.

Jhonston, S.R.D., 2005, Endocrinology and Hormone Therapy in Breast Cancer, Selective Oestrogen Receptor Modulators and Down Regulators for Breast CancerHave They Lost Their Way?, Breast Cancer Res., 7(3), II9-130.

Key, T.J.A, Chen, J., Wang, D.Y., Pike, M.C. and Boreham, J., 1990, Sex Hormones in Women in Rural China and in Britain, Br. J. Cancer, 62(4), 63I-636.

Ma'at, S., 2003, Tanaman Obat untuk Pengobatan Kanker, Jurnal Bahan Alam Indonesia, 2(4), I46-150.

Mills, S. and Bone, K., 2000, Principles and Practice of Phytoterapy, Modern Herbal Medicine, Edinburgh: Churcill Livingstone.

Oh, M., Choi, Y.H., Choi, S., Chung, H., Kim, K., Kim, S.l., et al., 1999, Antiproliferating Effects of Ginsenoside Rh2 on MCF-7 human breast cancer cells, Intl. J. Oncol., I 4(5), 869-875.

Raju, J., Patlolla, J.M.R., Swamy, M.V. and Rao, C.V., 2004, Diosgenin, A Steroid Saponin of Trigonella Foenum-Graecum L. (Fenugreek), Inhibits AzoxymethaneInduced Aberrant Crypt Foci Formation in F344 Rats and Induces Apoptosis in HT-29 Colon Cancer Cells, Cancer Epidemiol. Biomark. Prev, I3(8), I392-1398.

Smith, S.M.R. and Osborne, M.P., 2000, Breast Cancer Chemoprevention, Am. J. Surg. I 80(4), 249-25I.

Saputra, K., Maat, S. and Soedoko, R. 2000. Terapi Biologi untuk Kanker, Airlangga University Press, Surabaya.

Trott, O. and Olson, A.J., 2010, AutoDock Vina: Improving The Speed and Accuracy of Docking with a New Scoring Function, Efficient Optimization and Multithreading, J. Comput. Chem., 3 I (2), 455-46I.

Wuttke, D.S., Hesse, O., Jarry, H., Christoffel, V., Spengler, B., Becker, T., et al., 2003, Evidence for Selective Estrogen Receptor Modulator Activity in A Black Cohosh (Cimifuga Racemosa) Extract: Comparison With Estradiol-17 $\beta$, Eur. J. Endocrinol., I 49(4), 35I-362.

Wiryowidagdo, S. 200I. Kimia dan Farmakologi Bahan Alam, Jakarta: Universitas Indonesia Press.

World Health Organization, 2007, WHO Monograph on Selected Medicinal Plants Volume 3, Otawa: WHO. 